\title{
PCR-RFLP is a useful tool to distinguish two powdery mildew pathogens of flowering dogwood (Cornus florida)
}

\author{
Ainong Shi ${ }^{1,3}$, Stella Kantartzi ${ }^{2}$, Margaret Mmbaga ${ }^{3}$, and Pengyin Chen ${ }^{4}$ \\ 1 Syngenta Seeds, 2369 - 330th St. Slater, IA 50224, USA; ${ }^{3}$ Otis L. Floyd Nursery Research \\ Center, Tennessee State University, McMinnville, TN 37110, USA; ${ }^{2}$ Department of Plant, Soil \\ and Agricultural Systems, Southern Illinois University Carbondale, Carbondale, IL 62901, \\ USA; ${ }^{4}$ Department of Crop, Soil, and Environmental Sciences, University of Arkansas, \\ Fayetteville, AR 72701, USA. \\ *Corresponding author. Email: ainong.shi@syngenta.com or ainong_shi@hotmail.com. \\ ABSTRACT
}

The internal transcribed spacer (ITS) region of rDNA and the intervening 5.8S RNA gene for Erysiphe (Sect. Microsphaera) pulchra and Phyllactinia guttata, powdery mildew pathogens of flowering dogwood (Cornus florida) were analyzed using polymerase chain reaction (PCR), and polymerase chain reactionrestriction fragment length polymorphism (PCR-RFLP). While the two fungi displayed close bands with universal primer pair, ITS ${ }_{1}$ and ITS $\mathrm{IS}_{4}$ at $642 \mathrm{bp}$ and $659 \mathrm{bp}$, respectively, the ITS primers also amplified the host-dogwood DNA and displayed the band of about $710 \mathrm{bp}$. PCR-RFLP of the ITS region showed different patterns between $E$. pulchra and $P$. guttata after digestion with enzymes Alu I, Dde I, Hae III, Hinf I, Rsa I, and Sau3A I. PCR-RFLP would be a useful technique in disease diagnosis of anamorph stage of dogwood powdery mildew pathogens.

Keywords: Powdery mildew, Phyllactinia guttata, Erysiphe pulchra, dogwood, Cornus florida, PCR, PCR-RFLP, ITS

Abbreviations: PCR, polymerase chain reaction; PCR-RFLP, polymerase chain reaction-restriction fragment length polymorphism; ITS, internal transcribed spacer.

\section{INTRODUCTION}

Powdery mildew has become a widespread problem in flowering dogwood (Cornus florida) in nursery and landscape environments. The disease has been associated with reduced plant vigor, shoot and root growth (Mmbaga 1998), reduced flower-bud set and reduced spring bloom (Hartman 1998). The effect of this disease on established plants is largely cosmetic, but plant mortality in one year-old seedlings have been associated with severe disease outbreaks (Daughtrey and Hagan 2001). Two pathogens, Phyllactinia guttata (Wallr.) Lev. [syn. Phyllactinia corylea (Pers.) P. Karst.] and Erysiphe (sect. Microsphaera) pulchra (Cook \& Peck, Braun \& Takamatsu) have been associated with this disease (Braun et al. 2002; Braun and Takamatsu 2000; Daughtrey and Hagan 2001; Hartman 1998; Klein et al. 1998; Mmbaga 1998).

The two pathogens can be readily identified at the teleomorph stage (Klein et al. 1998; Mmbaga et al. 2004), but in dogwood, ascocarps are not available when disease symptoms are prominent. The anamorph (asexual) stage (Oidium sp. for E. pulchra and Ovulariopsis sp. for $P$. guttata), persists seasonlong, but the two pathogens cannot be easily distinguished using conidia or disease symptoms
(Barnet and Hunter 1998). A practical approach is to use molecular markers as a tool in the diagnosis of powdery mildew pathogens. ITS regions of DNA have been widely used in identifying and distinguishing pathogens for fungal diseases in plants (Braun and Takamatsu 2000; Godfrey et al. 2003; Saenz et al. 1999). Thousands of sequences of ITS regions from fungi have been published in the GenBank (http://www.ncbi.nlm.nih.gov). DNA sequences of ITS regions have been used to design ITS-specific primers and other PCR-based assays for diagnosis of plant pathogens (Casimiro et al. 2004; Lecomte et al. 2000; Mmbaga et al. 2004; Rehmany et al. 2000; Shi et al. 2006; Vandermark et al. 2000; Zhang et al. 1999). Molecular approaches have been widely used in distinguishing, identifying, and detecting powdery mildew pathogens in many plants (Adam et al. 1999; Cunnington et al. 2004a, 2004b; Kiss et al. 1998; Mmbaga et al. 2004; Mori et al. 2000; Takamatsa et al. 1998, 1999). PCR-RFLP has been used to distinguish and characterize different fungi (Guo et al. 2000; Manceau et al. 1997; Rivoal et al. 2003). Although two ITS primer pairs that distinguished $E$. pulchra from $P$. guttata at the anamorph stage have been reported (Mmbaga et al. 2004), our further studies showed the two identified ITS primer pairs 
were not species-specific for the two pathogens and also they amplified DNA of the dogwood leaves (Shi et al. 2004). The objective of this study was to conduct additional studies on the ITS region of the two powdery mildew pathogens using regular PCR and PCR-RFLP to provide a tool to distinguish the two pathogens in dogwood.

\section{MATERIALS AND METHODS}

Powdery mildew materials: In autumn 2003, samples of powdery mildew infected leaves were obtained from Kentucky, New York, North Carolina, South Carolina, Tennessee, and Virginia. In spring 2004, additional samples were collected from six locations in South Carolina, five locations in North Carolina, one location in Virginia, eight locations in Georgia, and five locations in Tennessee. At least four samples were collected from each location and in total more than 100 samples were collected. All samples collected in spring contained the anamorph powdery mildew, but samples collected in autumn had both teleomorph and anamorph stages. Ascocarps of $P$. guttata were observed in samples collected from only one location in Kentucky (Dr. John R. Hartman of the University of Kentucky, Department of Plant Pathology Extension Service, Lexington, $\mathrm{KY}$ ). Ascocarps of $E$. pulchra were observed in all locations including Kentucky. Ascocarps and mycelia were isolated from infected leaves; samples from the same location that had small amounts of mycelia or ascocarps were combined during DNA extraction. A total of 25 DNA samples were processed.

DNA extraction and amplification: Genomic DNA was extracted from the following materials (1) noninfected dogwood leaves, (2) $P$. guttata ascocarps, (3) $E$. pulchra ascocarps, (4) mixed ascocarps of $E$. pulchra and $P$. guttata; (5) unidentified conidia and mycelia, and (6) powdery mildew infected leaves. The DNA extraction was done by using DNeasy Plant Mini Kit (Qiagen Inc., Valencia, CA) following the instructions provided by the manufacturer.

The universal primer pair, ITS1 (tccgtaggtgaacctgcgg) and ITS4 (tcctccgcttattgatatgc) were used to amplify the ITS region in the six groups of DNA samples. The primer pair, ITS1-F/ITS4 (ITS1-F: cttggtcatttagaggaagtaa) was also used to amplify the ITS regions in the two pathogens, E. pulchra and $P$. guttata (White et al. 1990) (http://plantbio.berkeley.edu/ bruns/primers.html) .

The DNA amplification was performed in a DNA thermal cycler following standard PCR procedures with minor modifications. Each $50 \mu \mathrm{l} \mathrm{PCR}$ reaction mixture consisted of $36 \mu \mathrm{l}$ sterile $\mathrm{ddd}_{2} \mathrm{O}, 5 \mu \mathrm{l} 10 \mathrm{X}$ PCR buffer (Promega), $3 \mu \mathrm{l} \mathrm{MgCl} 2(25 \mathrm{mM}), 1.5 \mu \mathrm{l}$ dNTP (10 mM total, $2.5 \mathrm{mM}$ each), $1.5 \mu \mathrm{l}$ primer each (20 ng/ $\mu \mathrm{l}), 0.2 \mu \mathrm{l} \mathrm{Taq} \mathrm{polymerase} \mathrm{(Promega)}(5 \mu / \mu \mathrm{l})$, and $1.3 \mu \mathrm{l}$ template DNA (20 $\mathrm{ng} / \mu \mathrm{l})$. PCR cycles consisted of an initial denaturation step at $94{ }^{\circ} \mathrm{C}$ for 5 min followed by 40 cycles $1 \mathrm{~min}$ at $93{ }^{\circ} \mathrm{C}$ (denaturation), $1 \mathrm{~min}$ at $45{ }^{\circ} \mathrm{C}$ (annealing), $2 \mathrm{~min}$ at $72{ }^{\circ} \mathrm{C}$ (extension). An extension cycle at $72{ }^{\circ} \mathrm{C}$ for 5 min was used to terminate the reaction and finally at $4{ }^{0} \mathrm{C}$ soak. The PCR products were visualized in $1.5 \%$ agarose gels in $1 \mathrm{X}$ TBE, stained with ethidium bromide.

Sequence analysis of the ITS region: The PCR products were purified by use of QIA quick PCR Purification Kit (Qiagen Inc, Valencia, CA) (http://www.qiagen.com) following the instructions of the protocol from the manufacture. The PCR products were then sequenced by the Davis Sequencing Inc at Davis, CA (http://www.davissequencing.com). The complete sequence of ITS region amplified from the primer pair ITS-F/ITS4 including the sequences of the two primers was published in GenBank: AY870864 for E. pulchra and AY870865 for $P$. guttata, respectively.

\section{PCR-RFLP}

The PCR products were digested using six enzymes, Rsa I, Alu I, Dde I, Hae III, Hinf I, and Sau3A. The digestion of PCR products was performed following the instructions from the manufacturer (Promega) for each enzyme. Each digest reaction consisted of 2.0 $\mu \mathrm{l}$ RE 10X buffer, $0.2 \mu \mathrm{l}$ acetylated BSA $(10 \mu \mathrm{g} / \mu \mathrm{l})$, $16.8 \mu \mathrm{l}$ direct PCR product, and $1.0 \mu \mathrm{l}$ restriction enzyme $(10 \mu \mathrm{g} / \mu \mathrm{l})$. The digestion mixture was incubated at $37{ }^{\circ} \mathrm{C}$ water bath for $3 \mathrm{hr}$ or longer depending on the enzyme. The digestion products were visualized in $1.5 \%$ agarose gels in $1 \mathrm{X}$ TBE, stained with ethidium bromide

\section{RESULTS}

Sequence analysis of the ITS region: The universal primer pair, ITS1 and ITS4 amplified DNA from all samples. Dogwood healthy leaves showed one band of about $710 \mathrm{bp} ; P$. guttata ascocarps showed one band of about $660 \mathrm{bp}$, E. pulchra showed one band of about $640 \mathrm{bp}$. The mixed E. pulchra and $P$. guttata DNA showed two bands of about $660 \mathrm{bp}$ and $640 \mathrm{bp}$ for $P$. guttata and E. pulchra, respectively; the unidentified mycelia and conidia showed one band of $640 \mathrm{bp}$ corresponding to E. pulchra. DNA of powdery mildew infected leaves showed three bands, $710 \mathrm{bp}$, $640 \mathrm{bp}$, and $550 \mathrm{bp}$ corresponding to the host, $E$. pulchra and another unidentified fungus growing on 
the powdery mildew infected leaves. All tested sample of powdery mildew infected leaves showed similar results with two bands of about $710 \mathrm{bp}$ and $640 \mathrm{bp}$, corresponding to the band size of the host and $E$. pulchra, respectively.

The size of E. pulchra PCR fragment was $642 \mathrm{bp}$ and $680 \mathrm{bp}$ amplified from the primer pairs ITS $1 / \mathrm{ITS}_{4}$ and $\mathrm{ITS}_{1}-\mathrm{F} / \mathrm{ITS} \mathrm{T}_{4}$, respectively (GenBank Accession No. AY870864). The $P$. guttata PCR fragments were 659 bp and $697 \mathrm{bp}$ from ITS $1 / \mathrm{ISS}_{4}$ and ITS $1-\mathrm{F} / \mathrm{ITS}_{4}$ primers, respectively (GenBank Accession No. AY870865). The CG\% of the PCR products was 54.0 and 55.8 for E. pulchra and $P$. guttata, respectively. It was only slightly smaller when ITS1-F/ITS4 primers was used, 53.1 for $E$. pulchra and 54.7 P. guttata. However, the sequences of $E$. pulchra and $P$. guttata were very different and there was only $75.2 \%$ matching between them according to the tool LAIGN of

FASTA (http://fasta.bioch.virginia.edu/fasta www/lalign.htm).

The sequences of E. pulchra PCR product amplified by the primer pairs ITS 1 -F/ITS 4 and ITS $1 / \mathrm{ITS}_{4}$ were identical to the sequence of the locus AB015935 of $E$. pulchra var. pulchra in C. kousa reported from Japan in GenBank (Takamatsu et al., 1999). Results from this study differ slightly from the sequence of US samples reported in 2003 (GenBank Accession no AY224136, Mmbaga et al. 2003). This study used purified DNA and a slightly longer fragment of the ITS region was amplified compared to the 2003 sequence analysis (GenBank Accession no AY224136, Mmbaga et al. 2003). Samples of E. pulchra used in this study were from diverse locations in different States while samples in previous report were from different locations within Tennessee only. Results on the ITS region DNA sequence analysis did not show sequence variations between isolates from different states; all samples produced $100 \%$ match to the Japanese E. pulchra.

Results on the DNA sequence of $P$. guttata showed $100 \%$ match with previous results published in the GenBank (GenBank Accession no AY224137, Mmbaga et al. 2003). However, a longer ITS fragment was amplified: $697 \mathrm{bp}$ (AY870865) compared to the $596 \mathrm{bp}$ in the previous study (GenBank Accession no AY224137, Mmbaga et al. 2003). A comparison of the ITS DNA sequence of $P$. guttata in $C$. florida with information from the GenBank for other $P$. guttata showed $97 \%$ match to $P$. guttata on Calycanthus occidentalis host (GenBank Accession no AF011314); a 92\% match to $P$. guttata in Corlus cornuta host (GenBank
Accession no AF011315), and $P$. guttata in Corylus cornuta host. A comparison to other related powdery mildews species showed a $94 \%$ match to $P$. kakicola, $92 \%$ match to $P$. moricola, and $92 \%$ match to $P$. fraxinus.

PCR-RFLP analysis: When the PCR products from ITS $1 / I^{T} S_{4}$ and ITS 1 -F/ITS 4 amplifications were digested with restriction enzymes, E. pulchra and $P$. guttata showed different patterns of DNA fragments. The E. pulchra digestion using enzyme Alu I produced one strong band of about $270 \mathrm{bp}$ and two very weak bands of about $220 \mathrm{bp}$, and $190 \mathrm{bp}$, but the enzyme did not digest $P$. guttata. The sequences of PCR product from ITS ${ }_{1}$ F/ITS ${ }_{4}$ amplification showed that Alu I has two cutting sites to produce three bands, at $268 \mathrm{bp}, 223 \mathrm{bp}$ and $189 \mathrm{bp}$ and there were no cutting site in $P$. guttata (Table 1). On contrast, $P$. guttata after Ras I digestion produced two bands of $536 \mathrm{bp}$ and $161 \mathrm{bp}$, but the enzyme Ras I did not digest E. pulchra (Table 1). The other four enzymes, Dde I, Hae III, Hinf I, and Sau3A I also digested $E$. pulchra and $P$. guttata and produced bands that differentiated the two pathogens, however longer than $24 \mathrm{hrs}$ were needed for complete digestion and we did not get stable results from other five enzymes.

\section{DISCUSSION}

The standard PCR using universal primer pairs $\mathrm{ITS}_{1} / \mathrm{ITS}_{4}$ or ITS1-F/ITS4 did not produce distinctive bands between $P$. guttata and E. pulchra and thus it is not practical to use them as a tool for disease diagnosis of anamorphic of powdery mildew. The ITS DNA sequence was clearly different and was used to select restriction enzymes that distinguish the two pathogens in disease diagnosis. PCR-RFLP using restriction enzyme Alu 1 produced three fragments with E. pulchra and did not digest $P$ guttata and Rsa I produced two DNA fragments for $P$. guttata but did not digest E. pulchra (Table 1). The PCR-RFLP is a very good tool to distinguish two pathogens $E$. pulchra and $P$. guttata. Table 1 lists the theoretical digestion patterns for $E$. pulchra and $P$. guttata ITS region with six enzymes postulated by the program NEBcutter V2.0 (http://tools.neb.com/NEBcutter2/index.php). We did not get such patterns in each enzyme because of incomplete digestion. However, the digestion patterns for each enzyme are very different between the two pathogens although incomplete digestion is a problem. 
Agric. Biol. J. N. Am., 2010, 1(3): 208-212

Table 1. Comparison of the digestion pattern for ITS region (ITS-F to ITS4) between E. pulchra (EP) and P. guttata (PG).

\begin{tabular}{|c|c|c|c|c|c|}
\hline Enzyme name & $\begin{array}{l}\text { Function -cutting } \\
\text { site }\end{array}$ & $\begin{array}{l}\text { Cutting } \\
\text { location in } \\
\text { EP }\end{array}$ & Segment in EP & $\begin{array}{l}\text { Cutting } \\
\text { location in PG }\end{array}$ & Segment in PG \\
\hline Alu I & $\begin{array}{l}\mathrm{AG} \downarrow \mathrm{CT} \\
\mathrm{TC} \uparrow \mathrm{GA}\end{array}$ & $\begin{array}{l}268 \\
457\end{array}$ & $\begin{array}{l}268 b p+189 b p \\
+223 b p\end{array}$ & none & $697 b p$ \\
\hline Rsa I & $\begin{array}{l}\mathrm{GT} \downarrow \mathrm{AC} \\
\mathrm{CA} \uparrow \mathrm{TG}\end{array}$ & none & $680 b p$ & 536 & $\begin{array}{l}536 b p+ \\
161 b p\end{array}$ \\
\hline Hae III & $\begin{array}{l}\mathrm{GG} \downarrow \mathrm{CC} \\
\mathrm{CC} \uparrow \mathrm{GG}\end{array}$ & $\begin{array}{l}110 \\
156 \\
503\end{array}$ & $\begin{array}{l}110 b p+ \\
46 b p+ \\
347 b p+177 b p\end{array}$ & $\begin{array}{l}88, \\
184, \\
190, \\
212, \\
516\end{array}$ & $\begin{array}{l}88+ \\
96 b p+ \\
6 b p+ \\
22 b p+ \\
304 b p+ \\
181 b p\end{array}$ \\
\hline Dde I & $\begin{array}{l}\mathrm{C} \downarrow \text { TNAG } \\
\mathrm{GANT} \uparrow \mathrm{C}\end{array}$ & $264 / 267$ & $267 b p+416 b p$ & $\begin{array}{l}\text { 69/72, } \\
274 / 277\end{array}$ & $\begin{array}{l}72 b p+ \\
208 b p+ \\
423 b p\end{array}$ \\
\hline Hinf I & $\begin{array}{l}\mathrm{G} \downarrow \text { ANTC } \\
\mathrm{CTNA} \uparrow \mathrm{G}\end{array}$ & $\begin{array}{l}374 / 377 \\
382 / 385 \\
631 / 634\end{array}$ & $\begin{array}{l}377 b p+ \\
11 b p+ \\
252 b p+ \\
49 b p\end{array}$ & $\begin{array}{l}135 / 138 \\
380 / 383 \\
389 / 392 \\
397 / 400 \\
648 / 651\end{array}$ & $\begin{array}{l}138 b p+ \\
248 b p+ \\
12 b p+ \\
11 b p+ \\
254 b p+ \\
46 b p\end{array}$ \\
\hline Sau3A I & $\begin{array}{l}\downarrow \mathrm{GATC} \\
\mathrm{CTAG} \uparrow\end{array}$ & $\begin{array}{l}279 / 283 \\
357 / 361 \\
365 / 369\end{array}$ & $\begin{array}{l}283 b p+ \\
84 b p+ \\
12 b p+ \\
335 b p\end{array}$ & $\begin{array}{l}60 / 64 \\
317 / 321 \\
586 / 590\end{array}$ & $\begin{array}{l}64 b p+ \\
261 b p+ \\
273 b p\end{array}$ \\
\hline
\end{tabular}

\section{REFERENCES}

Adam, L., Ellwood, S., Wilson, I., Saenz, G., Xiao, S., Oliver, R. P., Turner, J. G., Somerville, S. (1999). Comparison of Erysiphe cichoracearum and $E$. cruciferarum and a survey of 360 Arabidopsis thaliana accessions for resistance to these two powdery mildew pathogens. Mol Plant Microbe Interact. 12(12):10311043.

Barnet, U., and Hunter, B. B., (1998): Illustrated Genera of Imperfect Fungi, $4^{\text {th }}$ edn. St Paul, MN: American Phytopathological Society Press, 218 pp.

Braun, U. and Takamatsu, S. (2000). Phylogeny of Erysiphe, Microsphaera, Uncinula (Erysiphaceae) and Cystotheca, Podosphaera, Sphaerotheca (Cystothaceae) inferred from rDNA ITS sequencesSome taxonomic consequences. Achlechtendalia:4:133

Braun, U., Cook, R.T.A., Inman, A.J., and Shin, H. D. (2002). The taxonomy of the powdery mildew fungi. Pages 13-55. In: The Powdery Mildews A Comprehensive Treatise. American Phytopathological Society Press, St Paul MN.

Casimiro, S., Moura, M., Ze-Ze, L., Tenreiro, R., Monteiro, A. A. (2004). Internal transcribed spacer 2 amplicon as a molecular marker for identification of Peronospora parasitica (crucifer downy mildew). J. Appl. Microbiol.. 96(3):579-87.
Cunnington, J. H.; Lawrie, A. C.; and Pascoe, I. G., (2004a). Unexpected ribosomal DNA internal transcribed spacer sequence variation within Erysiphe aquilegiae sensu lato. Fungal Diversity 16:1-10.

Cunnington, J. H., Takamatsu, S., Lawrie, A. C., and Pascoe, L. G. (2004b). Molecular identification of anamorph powdery mildews (Erysiphes). Australasian Plant Pathology 32(3):421-428.

Daughtrey, M.L., and Hagan, A. K. (2001) Dogwood diseases, pp124-132. In Jones, R.K., and M. D.

Godfrey, S. A., Monds, R. D., Lash, D. T., Marshall, J. W. (2003). Identification of Pythium oligandrum using species-specific ITS rDNA PCR oligonucleotides. Mycol. Res. 107:790-796

Guo, Y. H., Cheng Z. M., and Walla, J. A. (2000). Characterization of $\mathrm{X}$-disease phytoplasmas in chokecherry from North Dakota by PCR-RFLP and sequence analysis of the rRNA gene region. Plant Dis. 84:1235-1240

Hartman, J. (1998). Effect of dogwood powdery mildew incidence on flower set. In Proceedings of the Dogwood Workshop, CrossNore, NC, October 19, 1998. pp. $25-26$

Kiss, L., Nakasone, K. K. (1998). Ribosomal DNA internal transcribed spacer sequences do not support the species status of Ampelomyces quisqualis, a 
hyperparasite of powdery mildew fungi. Curr. Genet. 33(5):362-367.

Klein, L. A., Windham, M. T., and Trigiano, R. N. (1998). Natural occurrence of Microsphaera pulchra and Phyllactinia guttata on two Cornus species. Plant Dis. 82:383-385.

Lecomte, P., Peros, J. P., Blancard, D., Bastien, N., Delye, C. (2000). PCR assays that identify the grapevine dieback fungus Eutypa lata. Appl. Environ. Microbiol. 66(10):4475-4480.

Manceau. C., and Horvais. A. (1997). Assessment of genetic diversity among strains of Pseudomonas syringae by PCR-restriction fragment length polymorphism analysis of rRNA operons with special emphasis on $P$. syringae pv. tomato. Appl. Environ. Microbiol. 63(2):498-505.

Mmbaga, M.T. (1998). Effect of powdery mildew on plant growth of Cornus florida dogwood. In Proceedings of the Dogwood Workshop, CrossNore, NC, October 19, 1998, pp.4-6.

Mmbaga, M. T., Klopfenstein, N., Shi, A., Kim, M., and Mmbaga, N. C. (2004). PCR-based analysis of powdery mildew pathogens of dogwood (Cornus spp.). Forest Pathology J. 34:321-328.

Mori, Y., Sato., Y., and Takamatsu, S. (2000). Evolutionary analysis of powdery mildew fungi using nucleotide sequences of the nuclear ribosomal DNA. Mycologia 92:47-93.

Rehmany, A. P., Lynn, J. R., Tor, M., Holub, E. B., Beynon, J. L. (2000). A comparison of Peronospora parasitica (Downy mildew) isolates from Arabidopsis thaliana and Brassica oleracea using amplified fragment length polymorphism and internal transcribed spacer 1 sequence analyses. Fungal Genet Biol. 30(2):95-103

Rivoal, R., Valette, S., Bekal, S., Gauthier, J. P., and Yahyaoui, A. (2003). Genetic and phenotypic diversity in the grminaceous cyst nematode complex, inferred from PCR-RFLP of ribosomal DNA and morphometric analysis. Eur J Plant Pathol 109:227-241.

Saenz,G. S. and Taylor,J. W. (1999). Phylogeny of the Erysiphales (powdery mildews) inferred from internal transcribed spacer ribosomal DNA sequences. Can. J. Bot. 77 (1):150-168.

Shi, A., M. Mmbaga, and S. Zhou. (2004). Molecular analysis of powdery mildew in dogwood. Phytopathol 94:S95

Shi, A. and M.T. Mmbaga. (2006). Perpetuation of powdery mildew infection and identification of Erysiphe australiana as the crape myrtle pathogen in midTennessee. Plant Dis. 90:1098-1101.

Takamatsu, S., Hirata, T., Sato,Y., Nomura,Y. and Sato,Y. (1999). Phylogenetic relationships of Microsphaera and Erysiphe (powdery mildews) inferred from the rDNA ITS sequences. Mycoscience 40:259-268.

Takamatsu, S., Hirata, T. and Sato, Y. (1998). Phylogenetic analysis and predicted secondary structures of the rDNA internal transcribed spacers of the powdery mildew fungi (Erysiphaceae). Mycoscience 39:441-453.

Vandemark, G. J., Kraft, J. M., Larsen, R. C., Gritsenko, M. A., and Boge, W. L. (2000). A PCR-based assay by sequence-characterized DNA markers for the identification and detection of Aphanomyces euteiches. Phytopathol 90:1137-1144.

White, T. J., Bruns, T., Lee, S., \& Taylor, J. W. (1990). Amplification and direct sequencing of fungal ribosomal RNA genes for phylogenetics. Page 315-322 in: RCR Protocols: A Guide to Methods and Applications, eds. Innis, M. A., Gelfand, D. H., Sninsky, J. J., \& White, T. J. Academic Press, Inc., New York.

Zhang, A. W., Hartman, G. L., Curio-Penny, B., Pedersen, W. L., and Becker, K B. (1999). Molecular Detection of Diaporthe phaseolorum and Phomopsis longicolla from Soybean Seeds. Phytopathol 89:796-804. 